\title{
DEBATABLE ISSUES IN FIQH AL-ZAKAT: A JURISPRUDENTIAL APPRAISAL
}

\author{
By: \\ Mek Wok Mahmud* \\ Sayed Sikandar Shah Haneef**
}

\begin{abstract}
Zakat in terms of socio-economic role is a mandatory religious duty on the well to do members of the Ummah, to part with a portion of their wealth for the well-being of have-nots and helping other eligible social causes. To practically implement this policy, the Prophet laid down a comprehensive legal framework for its collection and distribution befitting the condition of his time. The classical jurists supplemented it by framing other operational laws to realize efficacious implementation of zakat at their time. In our contemporary time, jurists were faced with the question of efficacy of classical elaboration of zakat jurisprudence to serve the socio-economic objectives of zakat in modern time. Among others the adequacy of classical definition of zakat terms became debatable. The result was the usual divergence of opinions among the contemporary thinkers both with Shari'ah and Islamic economics backgrounds. This study is primary designed to critically evaluate the opposing views from fiqh perspective.
\end{abstract}

* Assistant Prof., Department of Fiqh and Usul al-Fiqh, Kuliyyah of Islamic Revealed Knowledge and Human Sciences, International Islamic University Malaysia, Kuala Lumpur.

** Assoc. Prof., Department of Fiqh and Usul al-Fiqh, Kuliyyah of Islamic Revealed Knowledge and Human Sciences, International Islamic University Malaysia, Kuala Lumpur. 


\section{INTRODUCTION}

Since early 20th century, some leading scholars have been fervently debating the possibility of making fresh ijtiha $\bar{d}$ on a host of newly emerging issues of fiqh al-zakât. This is asserted to be so due to radical changes that have taken place in the methods of producing new forms of wealth and the way that Muslims deals even with the traditionally designated zakat payable wealth. There are many issues ${ }^{1}$ that have engaged serious scholarly debate surrounding the fiqh of zakat. But for the purpose of this paper, we briefly highlight the current debate about issues, such as the adequacy of growth as the criterion for zakatablity of the wealth; contemporary definition of nisab; attempts at revising the rate of zakat, calculation of the hawl; and exemptible assets of the zakat payer. In this study therefore, different views for reform would be examining with the prime idea of offering a jurisprudentially valid position on the about mooted points.

\section{THEORETICAL FOUNDATION OF ZAKAT}

Zakat $^{2}$ literally means to grow and to increase and to purify. When it is said about a person, zaka nafsahu, it means to have

1 Abu Al-Ḥasan Sadeq (2004), A Survey of The Institution Of Zakat: Issues, Theories And Administration, Discussion Paper II. Riyad: Islamic Development Bank Islamic Research And Training Institute, p. 29.

2 It is to be remembered that Qur' an also uses the word sadaqah to imply zakāt, for instance, see al-A 'rāf: 156,Maryam: 31, al-Anbiyā': 72, al-Mu'minūn: 4. Similarly, the Prophet when dispatched Mu 'adh to Yemen,said: " inform them that Allah has prescribed sadaqah on their funds...". Nevertheless, it was later on that the jurists technically distinguished between șadaqah and zakät, the former refers to donation and voluntary charity while the later signifies compulsory financial obligation of the wealthy towards the poor. See Yūsuf al-Qaraḍāwì (1999), Monzer Kahf (trans.), Fiqh az-Zakat, London: Dar al Taqwa Ltd, pp.xlv-xlvi. See also Muhammad AbuSaud (1988), Contemporary Zakat. Cincinnati: Zakat and Research Foundation, pp. 9-12. 
improved himself and have become a better person ${ }^{3}$. According to Ibn Taymiyyah it implies the idea of making the soul of the zakat payer better(morally and spiritually) and his wealth clean ${ }^{4}$. This is succinctly clear from the declared ratio legis of zakat commandment according to the Holy Qur'an,

"take zakat from their wealth to purify and cleanse them."

Surah Al-Tawbah (9):103

Technically it stands for an act of monetary worship according to which any Muslim who possesses a wealth $(m a \bar{l} l)$ equal to or exceeding a laid down limit (nișāb) has to give away (in person or through (proxy), at the prescribed rate, a portion of it to specifically designated categories of people. ${ }^{5}$

Zakāt as such derives its validity from numerous verses of the the Qur'an and the prophetic traditions, among which, the following are most explicit. The Qur 'an', among others, provides:

"And they were commanded not, but that they should worship none but Allah alone and perform the salah and give zakat, and that is the right religion"

Surah al-Bayyinah (98): 5

"... and in their wealth and of possessions is assigned a right for the needy and those who suffer deprivation"

Surah al-Dhāriyāt (51): 19

"Muhammad; take out of their possessions sadqat so that you may cleans and purify them thereby, and pray for them)"

Surah al-Tawbah (9): 103

Ibid., p.xliii.

4 Aḥmad Ibn 'Abd al-Ḥalīm Ibn Taymiyyah (n.d.), Fatāwāa, vol. 25. Beirūt: Dār al-Kitāb al-'Ilmiyyah, p. 8.

5 Wahbah al-Zuhayli (1989), al-Fiqh al-Islāmī wa Adillatuhu, vol. 2. Beirut: Dar al-Fikr, p. 730.

6 The word zakāt occurs thirty times in the Qur'an and in twentyseven of them it is mentioned side by side with salah. for details see, al-Qaraḍāwī (1999), op.cit, pp. 9-22. 
The substance of the Qur'anic ayat are affirmed by many hadith $(\text { aha } \bar{a} \bar{d} \bar{i} h)^{7}$ of the Prophet:

Islam is based on five principles: "to testify that there is no god but Allah and that Muhammad is His Prophet, to offer the regular prayers, to pay zakat, perform hajjand to observe the fast. ${ }^{\prime 8}$

The Prophet sent Mu'àdh to Yemen and told him, "You are going to people of a Divine Book. First of all invite them to worship Allah (alone) and when they come to know Allah, inform them that Allah has enjoined on them five prayers in every day and night, and when they start offering these prayers, inform them that Allah has enjoined on them zakat which is to be taken from the rich among them and given to the poor among them. And if they obey you that, take zakat from them and do not take the best of their possessions."

Accordingly, zakāt like other pillars of Islam is another fundamental 'ibādah without whose fulfillment one's claim of loyalty to Islam will be seriously doubted and even negated. That is why Abu Bakr, the righteous Caliph, resolved to fight those who defied paying it, contending, among others, that any one who discriminate between the two pillars of salāh and zakāt, by doing the former and willfully rejecting the other, it would be legitimate to be fought against. ${ }^{10}$ The Prophet is also reported to have said:

7 Hadith the plural of which is ahädith means relayed information about the Prophet's, statements, practices and tradition which may either contain a legislation or it may just relate the Prophet's undertaking as administrator .In Islamic jurisprudence, the import of the hadith as such is called Sunnah,which is the second primary source of the hukm (law/rule) in Islam.

8 Al-Khațīb Tabrizīi (1994), Fazlul Karim (trans.), Mishkāt al-Maṣābīh, vol.1. Delhi: Islamic Books Services, p. 96.

9 Muḥammad ibn Yazìd Ibn Mājah (n.d.), Sunan Ibn Mājah, vol. 2. Beirūt: Dār Ihyya' al-Turāth al-'Arabì, p. 416.

10 This he said in response to 'Umar's objection to such a policy .For details see al-Khin et. op.cit., pp. 274-275. 
"He who pays it seeking the reward from Allah will be rewarded and he who refuses to pay it, we shall take it from him...."11

The rationale for such stern position of the Shari'ah about enforcement of zakat is that it, aside from being spiritually invigorating, is designed to serve the following socio-economic objectives:

1. To promotes economic growth and productivity through the circulation of wealth zakat stimulates economic growth in the sense that it either enables the poor and the needy to become economically productive or helps the state to channel the zakat fund to fund raising business sectors with the view of creating job opportunities for the needy and the jobless. ${ }^{12}$

2. To meet the consumption demand of the poor thereby enhancing their purchasing power for goods and services.

3. To check the tendency for hoarding the idle money, hence leads to production of goods ad service.

4. To finance projects such as education, medical care and social welfare again raising productivity of the poor. ${ }^{13}$

5. To ensure equitable distribution of wealth through this means. Islam by instituting zakat aims at forestalling the creation of unnecessary unjust gap between the living standard of the poor and the rich, thus avoiding the most serious malady that afflicts the capitalists society. ${ }^{14}$ Accordingly it serves as a basic system for implementation of socio-economic justice of Islam by which a certain portion of the income is transferred from the haves to the have-nots. ${ }^{15}$

11 Aḥmad Ibn al-Husayn al-Bayhaqī (n.d.), al-Sunan al-Kubrā, vol. 4. Multan: Nasyr al-Sunnah, p. 105.

12 Ibid., pp. 41-42.

13 Imtiazi et.al (eds.)(2000), Management of Zakat in Modern Muslim Society. Riyad: IDB,IRTI, p. 11.

14 Al-Zuhayli (1989), op.cit, p. 372.

15 Monzer Kahf (1991), "Zakat: Unresolved Issues in Contemporary Fiqh", in Development and Finance in Islam, Sadeq et.all(eds.). International Islamic University Press, p. 174. 


\section{SOME FIQHI ISSUES IN THE CLASSICAL FIQH}

\section{The Criterion of Zakatability}

The classical jurists by looking at the application of zakat on the traditional sources of wealth, tried to identify the raison de'tre of zakatability of wealth. On the the principle of induction based the Prophet's designation of zakât payable wealth ${ }^{16}$, they, hence concluded that growth (namā) is bases of zakatability. Nam $\bar{a}$ in Islamic legal parlance refers to: First, something that provides the owner with profit or benefit. Second, something which is the result of growth in the form of surplus or a newly acquired item. ${ }^{17}$ For instance, profit in business is a kind of growth out of investment, livestock reproduction is another form of newly acquired asset. In these two examples money before investment has potential to grow, and animal naturally reproduces offspring. That is why they are considered zakāt payable assets. Accordingly, and made it a condition that any asset to be liable to zakat, it must either be actually growing or have the potential for growth.

For instance, al-Kasāni is quoted to have reasoned: "The meaning of zakat is growth and growth does not happen except when there is growing wealth. We do not mean by this that wealth automatically grows per se. But we mean that such wealth is susceptible to growth by some means such as grazing and trading. Grazing is the cause of having milk, reproduction and meat. Trading is the cause of realizing profits. In this context the cause substitutes the effect and the judgment is attributed to the

16 The Prophet imposed zakāt on certain heads of livestock other than those for work. He also declared business assets and idle money as zakatable. He also imposed zakat on certain types of agricultural crops, minerals and treasure troves. The classical jurists thus theorized that these implementations lead us to only one conclusion and that is, "only naturally growing or potentially growing wealth are subject to zakat." See Sunan Ibn Mājah, op.cit., pp. 416-422; Mishkāt al-Maṣābīh, op.cit, pp. 55-56; al-Qaraḍāwì (1999), op.cit., pp. 77-81.

17 Al-Qaraḍāwī (1999), ibid., p. 76. 
cause .... ${ }^{18 "}$ One of the implication of such a view in the filed of corporate sector is that zakat would be on the circulating wealth and not on the fixed assets of the company.

It is rational because zakat is legislated to help and relieve the poor without impoverishing the rich, by having the rich pay from their surplus, taking a little from the plenty. Imposing zakat on wealth that does not, by definition grow, reverses this purpose, since zakat is paid year after year, in addition to living expenses. ${ }^{19}$

In line with the above theory, the jurists ruled:

1. Assets held for personal and family use, such as household furniture and transportation are not subject to zakat.

2. Assets that do not grow, such as bad debts are also not subject to zakat. But idle money is subject to zakat because it is the fault of the owner who is lax in investing it which robs it of its potential to grow. ${ }^{20}$

3. All growing assets, according to the preponderant view of among jurists except with the Zahiriyyah, are subject to zakat. $^{21}$

\section{Legal-threshold for Zakat (nișāb)}

It is agreed by the majority of the classical jurists that there is no zakat on all growing wealth but those reaching the minimum laid down limit as set by the Sunnah (nișāb). The Prophet is on record to have exempted anything that is less than five camels, forty sheep,two hundred silver dirhams or five wasqs of grain. Abū Hanifah, bon the other hand, do not regard this to be a pre-requisite in the case of land crops, fruits and minerals. Nevertheless, the majority opinions is more rational as it would be imprudent to impose zakat on who themselves are in need of help. ${ }^{22}$

\footnotetext{
$18 \quad$ Ibid., p. 77.

19 This is opined by Ibn al-Ḥumām, the author of Fath al-Qadīr, cited in ibid.

20 Ibid., pp. 80-81.

${ }_{21}$ For details, see ibid., pp. 82-83.

22 Ibid., pp. 85-86.
} 


\section{The Ratio of Zakat}

It to be noted that once the above properties reach nisab, they will be subjected to four types of rates: ${ }^{23}$

a. $2.5 \%$ from the capital income

b. $10 \%$ or $5 \%$ from the land crops

c. according to detailed code of rates for livestock

d. $20 \%$ of the found treasures

As to why not a flat rate for all the zakatable assets? Ibn Taymiyyah rationalizes by saying that the ratio of zakat has to vary for the above types of wealth due to no or less involvement of human effort in acquiring them. ${ }^{24}$

\section{The Passage of a year over possession of the asset}

According to majority of the jurist, twelve full lunar months should pass over the possession of zakat payable asset from the beginning of its ownership. But this condition applies to capital assets, such as money, business stock and livestock. This is on a hadith where the Prophet says: "There is no zakat on ones wealth unless one lunar calendar year transpires over its possession." 25

The jurists have differed about the time that earmarks the zakat year for the purpose of determining the nișāb. Shāfi iyyah and Hanābilah held that the niṣa $b$ must remain constant throughout the year. To Hanafiyyah the nișa $b$ must be present at the end and beginning of the year and according to Mâlikiyyah the determining point of time is the end of the year.

In the case of earned income, such as crops, fruits, minerals and found treasure, including wages, salaries and professional fees it is not a condition as they are classified as earned assets(mal mustafäd).

23 Muhammad Akram Khan (2003), "Some Accounting Issues Relating to Zakat" in Islamic Studies, vol. 2, no. 1, p. 109.

24 Abū Sa'ūd (1988), op.cit., p. 32.

25 Sunan Ibn Mājah, op.cit., p. 424. 


\section{What to exempt from the zakat}

Some jurists held that before assessing the zakat, two requirements of the zakat payer must be subtracted from his zakatable income before deciding as to whether he has to pay any zakat. They are:

\section{a. Deduction of essential needs (hawà'ij așliyyah)}

This is a condition set by Hanafiyyah, Imām Bukhārī and Ibn Kathir. As to what does it means? Ibn 'Abidin, fitting his own socio-economic condition/standard of living, brilliantly delineate it as: "Those things that are used to avoid the realized or potential destruction of human beings; realized ones, such as expenses for living, clothing, personal weapons; and potential ones, such as the need to pay one's debt, tools for handicraft ,home furniture, animals for personal transportation and books for study. If a person has money designated for such needs, it is considered non-existent with regard to zakat. This is similar to the case of some one who has no water except that designed for drinking. This water is considered non-existent with regard to performing ablution, and one is allowed to perform tayammum instead." 26

However majority disagreed by saying that this condition is unnecessary as the condition of growth takes care of such needs by classifying them as non-growing asset. Nonetheless, the Hanafiyyah position is more in keeping with present requirement of modern life and is in harmony with the current taxation practices which exempt a certain amount when clearing people's payable taxes. Further, it is supported by the general legal implication of evidences from the Qur'an and the Sunnah. ${ }^{27}$

In The Qur'an, we read:

"They will ask you what they should give away? Say, what is surplus from your needs."

Surah Al-Baqarah (2): 219

\footnotetext{
26 It is quoted in al-Qaraḍāwi from his renowned commentary of alDūrr al-Mukhtār. See al-Qaraḍāwī (1999), op.cit., pp. 87-89.

27 See Abu Sa'ūd (1988), op.cit., pp. 72-73.
} 
According to Ibn Kathir, the surplus means what is in excess of you and your family's needs. ${ }^{28}$ One of the Prophet's hadith is also taken as supporting this understanding when he said: "Sadaqah is taken only out of wealth." ${ }^{29}$ According to alBukhari, this hädith makes it a condition that the payer and his family must not be in need. ${ }^{30}$ It is also supported by the Prophet edict in ordering the zakat collector(in case of fruit) to leave one third or one forth for the payer to spend on the neighbors, friends and relatives. ${ }^{31}$

Accordingly, the intention behind the above evidences is that all the spending must be made out of surplus wealth. But it must be noted, as al-Qaraḍ̄îi, cautions us that this condition only covers basic needs or essential goods and services that one needs to sustain himself and his dependents. It does not cover those things that are simply desired, or they may be considered luxury. ${ }^{32}$ For instance, expenditure on holiday, desiring to make certain purchases not in the immediate future, or buying big bungalows or luxury cars to escape the zakat are some modern examples of luxury since such items are neither customary nor reasonable needs. ${ }^{33}$ I believe the state should set clear guidelines $^{34}$ from time to time as to what can be considered essential needs, taking into account the fluctuating inflationary movement of the market price for goods and services that Muslims need for their daily subsistence in our time.

28 This is according to the opinion by Ibn 'Abbās who by way of exegesis maintained so. al-Qaraḍāwi (1999), op.cit., p. 89; See also Husayn Husyan Shahhatah (2002), "Muhasabāt al-Zakāt Li alMașārif al-Islāmiyyah: bayn al-Fikr wa al-Taṭbiq" in Abhāth Nadwat al-Taṭbīq al-Mu 'āṣir li al-Zakāh, vol. 2. al-Azhar: S.A. Kamel Centre for Islamic Economics, p. 23.

29 Sunan Ibn Mājah, op.cit., p. 432.

30 Al-Qaraḍ̄wī (1999), op.cit., p. 89.

31 Ibid.

32 Ibid.

33 Ibid., p. 16.

34 Abu Daud proposes the concept of consumer basket value that is normally determined by tax departments as we noted before. See Abu Saud (1988), op.cit., p. 77. 


\section{b. Deduction of debt}

This condition emerges from the conditions of complete ownership and the asset being above one's basic needs. Accordingly, it is another pre-requisite of zakat. But for the purpose of application, the jurists have differed in its details. Most importantly, they divided zakatable wealth into two categories: apparent (zähir)-can be seen by the poor and detected by zakat collector, such as livestock and crops, and non-apparent $(b \bar{a} t \bar{t}$ ) $)$-not easily known to others, such money in the safe box and business asset. ${ }^{35}$

Accordingly, with regard to the first category, some like Hanafiyyah held that it would be free from zakat if overwhelmed by debt or reduces the zakatable asset owned by the debtor. The reason being that zakat is a financial right due to the poor, the right of the creditor comes first before their right. Majority on the other hand, including Shäfi 'iyyah differed on this, saying that zakat being an act of worship partakes in Allah's right, thus takes priority over the right of the zakat recipients. ${ }^{36}$

With regard to non-apparent type, again majority ${ }^{37}$ held that debt prevents zakat or at least reduces zakat on the assets by the amount of the outstanding debts. Minority held that it does not.

Nevertheless, discussing the issue from the apparent and non-apparent type, even if not confusing, is irrelevant today. Because it is a relative concept, it may have suited the jurist's time and circumstances. Today due to the advance in the field of accountancy in business and the practice of safe-keeping one's personal assets with the banks no one can hide such assets.

\footnotetext{
35 Al-Qaraḍāwì (1999), op.cit., p. 90; See also Abū Saud (1988), ibid., pp. 61-62.

36 Al-Qaraḍāwī (1999), ibid., pp. 91-93.

37 They represent Ahmad, Abū Hanifah and al-Shāfi ${ }^{\circ} \bar{i}$ in his new opinion. See ibid.
} 
The significance of the above juristic discourse, however is that the opinion which says that debt prevents zakat is the preferred view because:

i. Caliph Uthman asked the zakat payers to pay back their debts so that he can start paying their $z a k a t^{38}$

ii. ownership in the case of debtor is incomplete

iii. the aim of zakat is to relieve those who are in need, debtor himself is one of them so his need comes first before that of the others.

iv. in our time, even wealthy people are burdened by loans of many kinds, and pay it by way of installments. ${ }^{39}$ Consequently, if such debts are not calculated as part of one's basic requirement for the purpose of calculating zakat, the whole life one would not be able to stay free of debt and pay the zakat.

\section{CONTEMPORARY CALLS FOR RETHINKING OF THE ABOVE ISSUES}

Since eighties where radical changes have occurred in the structure and nature of wealth, some thinkers have been calling for a fresh understanding of the above fiqhi issues for its just and consistent application in the modern time. ${ }^{40}$

As to what are the rationales for the case of renewal and reform (ișlăh wa al-tajdìd), the proponents maintain as follows:

1. Sticking to classical figh frame of reference would obviously excludes many contemporary forms of wealth from the application of zakat. In a study Kahf made an estimation

38 Ibid., p. 92.

39 The scholars when addressing the issue as to which kind of debts are deductible, expressed two views: both deferred and immediate, only the immediate type. However, for today's application, the first view which covers the deferred type encompassing the system of debt by part-payment in our time is the suitable legal stand to which we subscribe. For details see, ibid., pp. 94-95.

40 Kahf (1991), op.cit., p. 173. 
of zakat proceeds in eight Muslim countries and it was found that if the zakat was applied on livestock, agriculture, mining and monetary holdings, zakat proceeds would be between $0.9 \%$ and 2\%(except in Sudan where it is 4.3\%) of the GDP.But when an estimation was made beyond the classical fiqhi position the rate of estimated zakat proceeds increased to between $2.0 \%$ and $7.5 \%$ of the GDP. ${ }^{41}$

2. Upholding some of the traditional views on zakat may divert wealth from poor to the rich. For instance, the nisab of money if determined on the basis of silver, zakat may be imposed on the poor as silver has sharply depreciated in value as compared with gold. Similar anomaly will arise if we impose the zakat on the gross products of the crops as maintained by the classical jurists since all land produce will be subject to $10 \%$ or $5 \%$ zakat once the amount harvested reaches $653 \mathrm{~kg}$ of rice. Thus a paddy cultivator once obtains that amount (approximately RM 1800,00) has to pay its zakat. However, to calculate the nisab on the net amount after deducting the agricultural expenses and the farmer's own basic requirements would resolve this anomaly. ${ }^{42}$ Another way that this arises is by exempting the fixed assets from zakat. This is so because in the time of revelation business involved a very little fixed assets in a shop or a spot with a few business implements, but todays business involves large amounts of capital invested in fixed assets, such as land, buildings, machinery and fixtures .Hence, to impose zakat on stock and cash alone let say in the case of a manufacturing ${ }^{43}$ company would result in imposing zakat on the poor and sparing the wealthy.

\section{Issued to be revised}

Due to the above reasons, the case for reform presses for revising the following:

41 See for table based on an unpublished study in IRTI, 1987. See ibid., pp. 185-188.

42 Khan also raises the problem in the context of Pakistan. See Khan (2003), op.cit., pp. 104-105.

43 Ibid. 


\section{Growth as the base of Zakatability}

The classical notion of growth as the criterion of zakatability has been seriously questioned by Muslim economists. For instance, Kahf, criticizes it in many ways ${ }^{44}$ including the following:

First, it is said to be faulty as a concept. The reason being that it exempts fixed asset of a business entity form zakat but this is not unproductive as the theory made it to be. Instead, it equally contributes to the production process like the circulating wealth. To equate items devoted to personal use (quniah) to business fixed asset is invalid, since the latter is employed to make profit(in a sense is growing). The argument that the Prophet exempted primitive hand tools of production in ancient Madinah cannot be equated with modern machinery and plants of our time.

Secondly, it is argued that the classical jurists have not been consistent when they applied this on assets that do not grow at all. For instance, idle money (is like idle fixed asset)or trade inventory which is in loss or in debt which are not growing. Or when they excluded its application from wealth that do grow. For instance, exclusion of fodder fed livestock, trees and domestic animals.

Thirdly, it is also argued that the application of growth in agriculture produce is also arbitrary since they are not growing ,actually or potentially, as they themselves are the result of growth process. ${ }^{45}$ Moreover to assume that crops are the increase of land is also invalid as they are the increase of the seeds.

Fourthly, if growth is the raison d'tere ('illah)of zakatability then its absence ought to be a reason for the waiving. This is not the case as trade inventory is still zakatable even if it incurs loss.

Accordingly, thinkers such as Kahf feels that the classical jurists were mistaken in their ijtihad to shift from richness (ghina) as the textually declared 'illah for zakatability of wealth to that of growth, ${ }^{46}$ which needs to be reviewed .But what is the operational

44 Kahf (1991), op.cit., p. 181.

45 Abū Sa'ūd says the theory is misleading and unscientific. See Abū Sa'ūd (1988), op.cit., p. 70.

46 Kahf (1991), op.cit., p. 183; Mohd Daud Bakar also subscribes to the same view but like Kahf does not offer any practical formula 
definition of ghinā, he does not elaborate. Abū Sa'ūd seems to lay down a practical formula, though not in the context of ghina as the yardstick, when he says: "The theory of 'growth' as postulated by the past jurists is fraught with complexity and anomalies. In fact to apply it one must give the word so many arbitrary implications that the integrity of the theory itself is destroyed. At present we can hardly find any need or justification for such a theory. Suffice it to state that zakat is due on all economic goods once they exceed nisab, except for those goods acquired for personal use or consumption, as well as on all money in its different forms if the amount withheld exceeds the limit. ${ }^{47 "}$

On the other hand, some other contemporary thinkers like al-Qaradawi and official bodies/governmental still advocate the relevance and validity of growth as the base of zakatablity, which is reflected by the Saudi practice of exempting business implements and machineries from zakat because they do not grow. ${ }^{48}$

\section{What should be the niṣa b today?}

Nisab as pre-requisite derives its validity from many ahādith, some important among which are:

1. The best of sadaqah is that which is paid out of opulence. ${ }^{49}$

2. There is no zakāt on less than five camels, and there is no zakāt on less than five awsuq (measurement of volume) of grain and there is no zakät on less than awaq of silver (200 dirhams $).{ }^{50}$

Rationalizing the above limit of exemption, al-Dahlawi observed that the raison d'tere for such was that in the time of the Prophet five

for ghina as it can be more vague than the concept of growth, if left undefined. see Mohd.Daud Bakr(1991), "The Malaysian Zakat System: Law and Policy Reform" in Development and Finance in Islam, Sadeq et all(edits.), International Islamic University Press pp.4-12.

47 Abū Saūd (1988), op.cit., pp. 71-72.

48 Shaik and the fatwa by Majlis Tahqiq Masail Hadirah represent this groups' stand, see Sadeq, op.cit., p. 38.

49 Sunan Ibn Mājah, op.cit., p. 432.

50 Ibid. 
volume of grain (awsuq)was sufficient for one family consisting of three persons for one year. Thus the idea was to subject to zakat what was in excess of the above..$^{51}$

Building on this, $\mathrm{Abu} \mathrm{Sa}$ ' $\overline{\mathrm{u}} \mathrm{d}$ maintains that unlike the traditional understanding that all the above limit of exemptions are permanently fixed, one would state that if five awsuq was made a criterion for zakatablity of grains as it was enough to sustain a family in the time of revelation, it cannot be the case today.Accordingly the nisab of assets should be reviewed in accordance with actual changes in circumstances, which is a well-established principle of fiqh. ${ }^{52}$ This is also justified by textual evidences, such as the Prophet statement, "no zakat is due unless in case of affluence. ${ }^{53}$ Definitely a farmer harvesting five awsuq of rice in a country like Malaysia is not affluent nor it suffices him for a duration of one year. Abū Sa 'ūd therefore, suggests that there should be a flat rate of nișa $b$ for all zakatable wealth, on the rationale that "the basis of zakat is to exempt that amount of wealth which is considered, in a particular community, sufficient to sustain the family or individual for one year.... ${ }^{54}$ According to him, the procedure would be:

1. to determine the livelihood requirements of individuals and families (hawā'j asliyyah), similar to goods and services that comes under the definition of consumer basket for the sake of taxation in the West.

2. To determine the basket value in terms of money at the time of paying zakāt.

3. To regard the value of the basket as limit of exemption that should be deducted from the income before calculating the due zakāt.

In accordance with the above, Abū Sa'ūd suggests that we would overcome the disparity that arises from the classical notion of different niṣa $b$ for different items. ${ }^{55}$

$51 \quad$ Abū Sa'ūd (1988), op.cit., p. 75.

52 Ibid.

53 Sunan Ibn Mājah, op.cit., p. 432.

54 Abū Sa'ūd (1988), op.cit., p. 75.

55 He means to imply that the owner of five camels and harvester of five awsuq of grain would be subject to one standard limit of 
Kahf offers the rationale for such a rethinking when he maintains: "The reason why we need to rethink about the nișāb is that the relative prices of the items of zakat have been changing over time, for example, the values of the nișa $b$ amounts of gold and silver are quite different in the contemporary world and hence the existing nișäbs of different new items do not correspond to cost of living. Moreover, the relative importance of items in the basket of basic needs have also changed significantly. Under these changed circumstances, we need to think of deriving a formula of $n i s a b$ on new items which are derived by fuqahă, keeping in view the "nișäbs" of items in the Prophetic traditions, their relative prices and weight in the cost of living at that time and applying this formula to determine the nișāb of new items in the contemporary world. In particular, the nișa $b$ of Zakatable new items will have to be determined consistently. This is important in order to preserve the virtues of zakât and to achieve its objectives. ${ }^{56}$

Manan who also supports the same idea suggests the formula to consist of defining the standard of living of an average family in a given socio-economic context by following a national guideline so as to exempt that from zakāt. Any-thing beyond this is subjected to zakât. ${ }^{57}$

Raquibuzzaman, another proponent of the same proposes that we need to allow different niṣa $b$ and exemption limits for each country, as situations vary from country to country. His arguments is that the Prophet fixed those to suit the conditions of the Arab society in the seventh century. Reviewing them in line with todays conditions would not violate the Sunnah as to him there is no hadith to the effect. ${ }^{58}$ So to him nișāb should be the value of what is adequate to maintain a reasonable standard of living, and this

exemption. See Ibid., pp. 76-77., and also see Shawqi Ahmad Dunyā (2002), "Ta 'ammulāt fï Ba 'd al-Jawānib al-Fiqhiyyah li al-Zakāt", in Abhath Nadwat al-Tațbīq al-Mu 'āṣir li al-Zakāt, vol.1. al-Azhar: S.A .Kamel Centre for Islamic Economics, p. 22.

56 Kahf (1991), op.cit., pp. 13-15 \& 44-45.

57 Sadeq (2004), op.cit., p. 34.

58 Ibid. 
should be changed from time to time to reflect the changes in the cost of living. ${ }^{59}$

On the contrary others ${ }^{60}$ who oppose this idea in principle, some of them allow it when the conventional rates and nișa $b$ are not sufficient to remove mass poverty .To this, they maintain that there is a precedent by 'Umar who changed the zakat rates on horse. ${ }^{61}$

The main arguements is that nișāb and the rates of zakat are fixed by clear directives of the Qur'an and Sunnah. Therefore, based on the established principle of ușul al-fiqh, "no ijtihād is allowed on issues covered by textual evidences (lä ijtahād fi mawrìd alnașs)." Accordingly such laws become part of immutable laws of the Shari'ah. Any deviation from this principle can lead to unfortunate results. The reason being that if changes in the zakat rates are allowed, this could lead to frequent changes in the zakat rates depending on the expediency of the ruling authorities (and it may even become an election issue in countries having multiparty systems) and this will destroy the sanctity of zakat which is a form of 'ibādah. ${ }^{62}$ Majlis Taḥqiq Masāil Haḍirah of Pakistan, a body representing this stand strongly opposed the government intention to revise the nișa $b$, among others, by contending that these laws do not derive their legislative validity from ijtihād to be revised and reopened but from the Qur 'an, hadith and ijma'. They rebutted the contention that due to big gap between the value of gold and silver, we need to rethink of the issue, by saying that it is not a new issue, it has happened in the time of the jurists but they did not alter the law as it would be ultra vires of Sunnah and ijmā' '.63 In terms of economic effect also, the Majlis said, "an increase in niṣa $b$ will lead to a fall in the number of zakat payers and an increase in that of zakat receivers. It will result in two problems. First, demand for zakat will be more than supply. Second, it will

\footnotetext{
$59 \quad$ Ibid., p. 35

60 Ibid., See also Mushfiqur Rahman ( 2003), Zakat Calculation Based on al-Qaradāwīi, United Kingdom: The Islamic Foundation, pp. 3-5.

${ }_{61}$ People like Shaik suggest this. See Sadeq (2004), op.cit., p. 35.

62 Ibid.

${ }^{63}$ Ibid., p. 35-36.
} 
appear that zakat encourages living on others, which is not really encouraged in Islam." 64

Al-Qaraḍāwi, also while opposes any rethinking on areas such as nisāb and rate, mainly because zakat, according to alShātibi is, 'the kind of transaction that have some characteristics of worship', thus we have to limit ourselves to the texts. Accordingly, to al-Qaraḍāwi , such matters are clearly defined by the texts and agreed by ijma'. He thus concludes: "I disagree with those who claim that the minimum exemption and rates of zakat are subject to change according to changing circumstances, on the grounds that such changes conform to the objectives and common benefits of zakat. I believe that such changes alter the features of zakat and reduces it to a mere civil tax, like any other taxes imposed by the government. ${ }^{65 "}$

The Saudi zakat administration while favor such a hard line stand on this issue, admits changes but within the sub-structure of textually defined nisab. For instance, due to that fact that the relative prices of gold and silver have changed, it follows the value of gold (i.e., 85 grams of gold), ignoring the value of silver to determine the niṣa $b$, which is the case in Pakistan. ${ }^{66}$

\section{The problem with the proposed revised niṣa}

The rationale of nișāb according to classical fiqh was to impose zakat on the wealthy and not on the poor, i.e.,it is an indicator (mazannah) of ghina (affluence). If this is taken literally, a farmer who today harvests five awsuq of wheat and needs multiple of that amount to fulfill his other needs, for all practical purposes is poor. Accordingly, as maintained by Shawqi, taken this rational together with the textual evidences which state that sadaqah is on the affluent (ghani), we need to rethink about the nișäb. But this option itself is beset with complexity. For instance, how to objectively determine ghina? Even if we adopt the Hanafiyyah criterion of imposing zakat on the nișa $b$ which is beyond the level of the zakat payer's subsistence (al-häjat al-aṣliyyah), the

\footnotetext{
${ }^{64} \quad$ Ibid., p. 36.

65 Al-Qaraḍāwī (1999), op.cit., p.xxxviii.

66 Ibid.
} 
question is: why do we still need to require the surplus to amount to the jurisprudentially defined concept of nișāb? Or shall we stick to the condition of yearly term, arguing that any one who has a surplus/saving amounting to nișāb, that is a sign of his ghinā? If we abandon both the criteria of nișa $b$ and ghina and advocate flat rate for all types of property, what would be the juridical base of such an option? ${ }^{67}$

\section{Revision of the rate}

On the revision of the rate. Kahf though do not offer any practical formula, suggests that the fixation of rates should be consistent with the prescribed rates keeping in view the matters of wealth transformability and the multidimensional nature of dynamic activities in the contemporary world. This would enable the state to redistribute a sizeable amount of wealth from the rich to the poor, and in view of the fact that the rich tends to indulge in "conspicuous consumption" beyond social limits of consumable durables. ${ }^{68}$

This is again not agreed by al-Qaradāwi $\bar{i}$ and others as it would be ultra vires of the Sunnah. ${ }^{69}$ Al-Farah also subscribes to this view by maintaining that no ijtihad on textually defined measure of 'ibadat. It is also rationale that Islam in prescribing the rate has anticipated the interest of both the zakat payer and the beneficiaries. ${ }^{70}$

67 Dunia (2002), op.cit., pp. 21-23.

68 Sadeq (2004), op.cit., p. 34; See also Muhammad Nejatullah Siddiqi (n.d.) Muslim Economic Thinking: A Survey of Contemporary Literature- Part Three, First International Conference On Islamic Economics (Selected Papers), retrieved on 26/01/2007 from http:// www.financeinislam.com.

69 Al-Qaraḍāwi (1999), op.cit., p. xxxviii.

70 'Abd al-Fațtah Muhammad Farah (1997), al-Tawjih al-Istithmārì li al-Zakāt. Dubai: Bank Dubay al-Islami, p. 28. 


\section{What to exempt?}

The scholars while agreeing with the traditional exemption of wealth that the zakat payer needs for fulfilling his livelihood requirements, they disagreed with the following:

\section{Fixed assets of the business}

For instance, Kahf says: "Consistency requires imposition of zakat on fixed assets, for example. This is because both of "circulating assets" and "fixed assets" contribute to production process and hence, to be consistent, both should be Zakatable." ${ }^{11}$ He continues by saying: "it is not right to say that fixed assets are zakatable only if these produce any return. The latter opinion is inconsistent because idle cash is considered Zakatable even if it does not produce any return, but fixed assets are exempted for not earning return. This will imply favoring large holdings and penalizing small ones, since the use of fixed assets varies directly with firm size. This lacks Islamic rationality. ${ }^{72 "}$

Other scholars like Abū Zahrah, Khallāf, Hassan and AlQarḍāwi differed with Kahf by maintaining that only the return would be zakatable and not the fixed assets. ${ }^{73}$ OIC Fiqh Academy in 1985 also held that fixed assets are not subject to zakat, which is reflected in the Saudi application of zakat. ${ }^{74}$

\section{Type of deductible loan}

In our time situation where one incurs debt is different from the time of the classical jurists. Every one, particularly in the wealthy country starts to be burdened by the running debts the moment he steps into the primary school. By the time he becomes a bread earners ,he is heavily burdened by loans against residential houses, cars even business. Accordingly, if the stipulation of exempting debt from zakat is not understood correctly, many affluent people

\footnotetext{
$71 \quad$ Kahf (1991), op.cit., p. 11.

72 Ibid., p. 13.

73 Sadeq (2004), op.cit., p. 32.

74 Scholars like Mawdūdi and 'Awad also propound the same legal stand, see ibid., p. 33.
} 
with expensive cars, houses etc would be exempted from zakat. Shafiqur Rahman seems to advance an enlightened opinion on this by saying that by agreeing that loans that one incurs on these items definitely come under the definition of basic necessity. Now a question arise: are all types of debts deductible? He answers it in the negative and offers a formula of deductible loans as follows:

a. Be of modest type and not of lavish and extravagant type. Thus the loan of a luxurious car and house would be deductible to the extent of the price of a modest type and any thing over and above it would not.

b. Be considered as a basic necessity. For instance, one car in good condition that suffices for a small family is a necessity but the second one not. Hence only the loan of the first car qualifies as deductible debt

c. Interest accruing on such debts should not be deductible In this way, he rightly points out, that we can strike a balance between the two extremes positions of either not exempting debts at all when calculating zakàt or deducting all types of debts whether necessary or not. ${ }^{75}$

\section{ANALYSIS AND EVALUATION}

From the above, an ordinary citizen (layman) would have two sets of laws in accordance to which, he is supposed to fulfils his obligations of zakāt. The most perplexing question confronting him in this process is obviously one of: which law, new or old, should he follow? Another dimension, mostly ignored by our well-intentioned scholars from a layman perspective, is which one is the correct law. In the lines that follow, I based on my reading of both the old fiqh and the new debate suggest the following:

\section{On the case-justification for reform}

Firstly, no one should dispute the need or the extension of zakatablity base to include the new sources of income within the structure of textually defined types of wealth known to us. To this, there is clear directive from the Qur 'an that every wealth ( $m a l)$ has

75 Rahman (2003), op.cit., pp. 32-37. 
to be cleansed and its owner purified. Thus this point for rethinking as raised by Kahf should no longer be a point of polemics between the modern and conservative 'ulama.

Secondly, the goal-frustrating juristic ruling of subjecting every five awsuq of grains or fruits to zakat, without considering the subsistence requirements of the farmer and his cost of farming though supported by the ruling of some fuqaha, cannot stand the force of prohibiting the imposition of zakat on the poor, i.e, "no zakat except on the opulence" and the Hanafiyah requirement of zakatable assets to be above one's basic needs. Hence, this issues should also rest as settled as modern legislation in some jurisdictions like Pakistan have already enforced this maqāsidoriented and internally consistent position of the law.

Thirdly, definitely, the distinction between modern types of fixed assets and the primitive tools of business is a real case for reform but it needs to be finally settled by legislation .

\section{On the growth as the base of zakatability}

One would agree on the questionability of the growth theory from an economic stand point as well as its somewhat inconsistent application in identifying the zakatable wealth by its jurist architects. But to say that the classical jurists erred in applying this to impose zakat on idle money or trade inventory amounts to exceeding the limits of rationality when one deals with matters of Islamic law. These two items were made zakatable by unimpeachable evidences from the Qur'an and the Sunnah. Again dismissing such a well-established theory in favor some vague concepts like ghina, I am afraid, would not advance any case for reform. On this issue, however, one would favor the proposition laid down by Abu Saud as a viable criterion (any economic goods that reaches the niṣa $\bar{b}$ ).

\section{On the Niṣāb}

Here we are confronted with two conflicting interpretations; one premised on the text of the hädith, another on their purported ratio legis as construed by renowned al-Dahlawi. If we go by the ratio legis of the law and say good by to the textually fixed nisă $b$, then 
the questions is: can the human constructed reason de'ter of the law overrule the letter of the law itself? There is unanimity among the legal scholars that in matters of 'ibādat it would be ultra vires of the juristic activism in the context of Islam. That is why Kahf was aware of this restriction when he suggested that such may be the course in the case of new forms of wealth but not in the case of those specified by textual sources (nușuss). On this issue therefore, the stand by the opponents of change is to be upheld as is in line with the fixation of nisā by unimpeachable evidences from the sunnah (contrary to what has been the claimed). ${ }^{76}$

\section{On the rate}

The question of rate, I believe, also involves touching the stable part of zakāt with the intention of augmenting the zakāt revenue. Definitely it may have good economic reason but jurisprudentially it raises the question of modifying the textual law by the flux of human rationally construed economic expediency. Thus, the classical position still reigns supreme and the economic reason for augmenting the zakāt revenue, which is the motive for re-rating, can be fulfilled through developing the mechanisms for investing the zakāt fund in productive ventures as maintained by Farah. ${ }^{77}$

\section{On deductible assets}

Excluding the fixed assets of business from zakāt can no longer be supported by economic reality of their role in today's business productivity. One may agree with reform proposals in this area. This is similar to the redefinition of zakat beneficiaries in our time and well come within the province of human reasoning (ijtihād). But for the practical implementation, it still remains a point of academic interest unless it is backed by state legislation.

Definition of deductible loans as proposed by Shafique is a judicious construction which should be regarded as correct statement of the law on the type of deductible debts.

76 The scholars of hadīth like al-Bayhaqi regards the ahā $\bar{i} \bar{t} h$ prescribing the niṣāb as authentic.See al-Bayhaqi (n.d.), op.cit., vol. 4, pp. 81107.

77 Farah (1997), op.cit., p. 28. 


\section{CONCLUSION AND RECOMMENDATION}

The main trend of thoughts emerging from a review of the available literature on debate about adjusting certain features of zakàt jurisprudence are as follows:

1. Any discussant who deals with sensitive issues Islamic law such as zakät must bear mind that there are parts of zakāt laws that can be reviewed and there are other aspects that are not amenable to human extrapolations. On the renewable part ,we argued and agreed with the extension of zakât base to include all economic goods and services of our time. We also agreed that today's fixed assets is a growing wealth in the economic sense and not in the legal sense as defined by the classical jurists, thus it has to be zakatable. We also favor the fresh understanding of deductible debts as today even most wealthy people are not free of running debts of some kind. On the fixed parts of the law, such as nișa $b$ and rate we beg to differ with modern views as they represent the permanent features of zakät as an act of 'ibādah. To augment the zakāt revenue, we alternatively, fully support the idea of utilizing zakât surplus fund in productive projects to create job, training and capital for the beneficiaries.

2. It should also be noted that zakāt though a fundamental component of Islamic fiscal system, in the context of Islamic state, is not a tax per se. Accordingly, the idea of its reform must be informed by the principles of Islamic jurisprudence and not by the postulates that govern the taxation laws in a capitalist economy. 
